\title{
Young teachers' professional identity in the conditions of social, labor, and digital transformation of Russian society
}

\section{La identidad profesional de los jóvenes docentes en las condiciones de transformación social, laboral y digital de la sociedad rusa}

\author{
Anatoly Vladimirovich Lubsky \\ Southern Federal University, Rostov-on-Don, Russia \\ https://orcid.org/0000-0001-9018-1092 \\ Galina Igorevna Chikarova \\ Southern Federal University, Rostov-on-Don, Russia \\ https://orcid.org/0000-0002-7499-5472
}

*Correspondencia

Email: avlubsky@gmail.com 


\section{Summary}

In society, there is a perception of young teachers as the future of the Russian education system who need constant patronage due to their lack of professional experience and skill. However, young teachers present not only a professional resource for the future of Russian education but also a social group with its own interests and values that is able to make a significant contribution to the development of general education in the present. Study proposes a multidimensional methodological construct of the sociological study of the professional identity of young teachers in Russian society developed within the "soft conception" of identity with consideration of both Russian and foreign theoretical and methodological experience. The internal and external factors for the formation of young teachers' professional identity, as well as the structure, functions, and the real and ideal types of this identity are identified. The detection of tendencies in the development of real professional identity allows identifying the direction of the transformation of young teachers' professional identity in Russian society via the comparison with ideal types.

Keywords: "soft conceptions" of identity, professional identity of young teachers, young teachers' professional identity types, theoretical reflection.

\section{Resumen}

En la sociedad, existe una percepción de los profesores jóvenes como el futuro del sistema educativo ruso que necesitan un patrocinio constante debido a su falta de experiencia y habilidad profesional. Sin embargo, los profesores jóvenes presentan no solo un recurso profesional para el futuro de la educación rusa, sino también un grupo social con sus propios intereses y valores que es capaz de hacer una contribución significativa al desarrollo de la educación general en el presente. El estudio propone un constructo metodológico multidimensional del estudio sociológico de la identidad profesional de los jóvenes docentes en la sociedad rusa desarrollado dentro de la "concepción blanda" de la identidad con la consideración de la experiencia teórica y metodológica rusa y extranjera. Se identifican los factores internos y externos para la formación de la identidad profesional de los jóvenes docentes, así como la estructura, funciones y los tipos reales e ideales de esta identidad. La detección de tendencias en el desarrollo de la identidad profesional real permite identificar la dirección de la transformación de la identidad profesional de los jóvenes docentes en la sociedad rusa a través de la comparación con tipos ideales.

Palabras clave: "concepciones blandas" de identidad, identidad profesional de los jóvenes docentes, tipos de identidad profesional de los jóvenes docentes, reflexión teórica.

\section{Introduction}

The contribution to the development of general education largely depends on the level of the human capital of young teachers, which is inextricably linked to their social and professional competencies. Within the "generational theory" (Howe, Strauss, 1991), young teachers can be attributed to the generation of millennials who were born in the digital age and have great educational capital and innovative potential. Thus, young teachers as the 
representatives of the "impatient" millennial generation are constantly searching for the opportunities for rapid professional growth and material success on the one side and strive for social self-realization on the other. Due to this, young teachers are more professionally mobile and less tied to individual organizational structures.

In the conditions of social, labor, and digital transformation of Russian society, young teachers possess a unique professional identity as the basis for their social and professional consolidation ensuring their ability to construct answers to the challenges of the Russian education system. However, the study of the professional identity of young teachers constantly makes researchers face theoretical and methodological difficulties.

\section{Literature review}

The results of the study of specific questions of teachers' professional identity in Russian society have already been summarized in the scientific literature. For instance, a dissertation on the professional identity of teachers as the subjects of labor activity notes that previous sociological works especially focused on the questions of social status, financial state, level of claims, professional competence, and ideal types of teachers in educational schools with different statuses (Shakurova, 2014). A different dissertation summarizes the results of sociological research of the questions of social adaptation and professional identity of physical education teachers presented in the works of Russian sociologists (Andrianov, 2014). A dissertation focused on the subject of social and professional identification of teachers accentuated the psychological and social aspects of schoolteachers' professional identity (Shliakov, 2008).

Aside from dissertations, some conclusions on the results of the sociological study of the professional identity of teachers were also made in scientific articles. An article covering the results of an international study of schoolteachers' professional identity already examined the aspects of the formation and development of said identity, the transformation of teachers' professional identity related to school education reforms, and the relation of this transformation to the effectiveness of pedagogical work (Berberian et al., 2019). A different article examining the professional identity of urban teachers in the conditions of education modernization also contains a brief review of the preceding scientific literature. In this review, the authors note that the substantial and dynamic characteristics of the professional identity of schoolteachers have started to serve as the object of sociological research increasingly more often in recent years. Moreover, they note that teachers' professional identity is often studied outside the context of the modernization of Russian education (Klimenko, Posukhova, 2017). A summarization of previous theoretical and methodological experience of the study of teachers' professional identity was also attempted in scientific works. The authors note that scientific research practice proposes various approaches to the definition of the concept of the professional identity of schoolteachers (Berberian et al., 2019), as well as diverse sociological tools (Shliakov, 2008).

Therefore, some works have already examined the results of the study of specific questions related to the professional identity of schoolteachers in Russian society. However, scientific literature has not yet presented an overall summary of the results of the study of the professional identity of young Russian teachers and the theoretical and methodological problems of its sociological study have not been identified. The above-mentioned factors problematize the topic of our study. On the one hand, the present study aims to identify the theoretical and methodological problems of the sociological study of young teachers' professional identity based on a critical analysis of modern scientific literature. On the other hand, its goal is to disclose the scientific potential of a multidimensional methodological construct of the sociological study of the professional identity of young teachers in the conditions of social, labor, and digital transformation of Russian society developed within the "soft conception" of identity with consideration of both Russian and foreign research experience. 


\section{Methods}

The criticism of scientific literature covering the professional identity of young teachers was based on the methodological principles of discourse analysis aimed at the identification of subject fields of disciplinary research practices and the detection of its scientific results. To conduct a critical analysis of the modern system of sociological knowledge on young teachers' professional identity, in the course of the bibliographic search, we selected scientific research studies published in the past 10 years and further systematized them into three groups: Russian publications summarizing the results of the study of the professional identity of teachers; Russian publications examining specific aspects of the study of young teachers' professional identity; the works of foreign researchers examining theoretical questions related to the study of professional identity as a whole and professional identity of teachers in particular which allowed us to use the theoretical potential of foreign studies in the development of the methodological construct.

The study also implemented the methodological capabilities of cognitive modeling allowing developing the methodological construct of the sociological study of young teachers' professional identity in Russian society in the context of its social, labor, and digital transformation. The construct allows creating a conceptual model of studying the professional identity of young teachers as a holistic social reality on the one hand and indicate the most perspective ways of its sociological study on the other.

\section{Results and Discussion}

Russian scientific, primarily psychological literature has already examined certain aspects related to the study of teachers' professional identity including the aspect of differing professional experience. It is noted that middle-aged teachers present the most stable and prosperous in a school setting. This finding is explained by the fact that middle-aged teachers demonstrate a quite high level of professional mastery and stable self-identification with the professional community while in young teachers, the professional self-image related to acquiring a new social status and a professional role is only forming (Siniakova, Shneider, 2011).

Sociological literature pays special attention to the professional and life values of young teachers (Luchkina, 2012). Researchers indicate that the main life values of young teachers are related to happy family life, successful professional activity, and achieving financial well-being. Professional values of young teachers mostly match the values of teachers in general, however, in their value and rational behavior, young teachers do not yet make full sense of the goals of school at the modern stage of its development. Moreover, researchers highlight the difficulties young teachers face in the process of "entering" their profession. These difficulties are related, on the one side, to young teachers' insufficient practical readiness for work at school and on the other, to their excessive self-confidence in their abilities and professional capabilities (Shchetkina et al., 2015; Khoshimova, Tagoeva, 2017).

Sociological literature also focuses on the internal and external factors of the formation of professional identity in young teachers. The factors researchers consider internal include the motives of young teachers' choice of the teaching profession, their professional values and professionally important qualities, satisfaction with life and the educational process (Sivrikova et al., 2017; Chernikova et al., 2017; Maslinskii, Ivaniushina, 2016), and readiness for professional activity (Gladkaia, 2012).

Postgraduate pedagogical education is viewed by researchers as one of the external factors of the formation of young teachers' professional identity. Scholars note that educational 
process individualization contributing to the development of young teachers' professional mastery and ensuring their professional development plays an especially significant role in said education (Shevchenko, 2014). The identification of the external factors of young teachers' professional identity formation also involved examining specific questions related associated with the school education system reforms and the socio-economic risks faced by teachers in the course of their work (Volchik, Posukhova, 2017). Some researchers accentuate the fact that reforms in the school education system related to the introduction of Federal State Educational Standards, an increase in administrative and work loads not accompanied by a rise in wages and the social status of the teaching profession have a destructive impact on the professional identity of a teacher and can bring it into a diffusive state (Klimenko, Posukhova, 2018).

Examining the effect of social and labor transformation of Russian society on the formation of the professional identity of schoolteachers, scholars highlight the precariatization of teaching. The precariatization of teachers' labor manifests in the system of general education in noncompliance with their social and labor rights, the social and economic vulnerability of teachers, increased workload not followed by a rise in wages, job loss risks, and the decline of social prestige of the teaching profession. All the above-mentioned factors generate a phenomenon of a pseudo-positive professional identity of teachers with the elements of identity diffusion (Klimenko et al., 2018).

Therefore, Russian scientific literature has already examined various aspects related to the formation of teachers' professional identity, young teachers included. However, the specific features of professional identity in young teachers in the conditions of social, labor, and digital transformation of Russian society have not yet been an object of special sociological research. Sociological studies on the effect of the digital transformation of Russian society on social and professional self-identification of young teachers and the degree of their consolidation with the professional community as a whole are also lacking.

Meanwhile, foreign literature already pays extensive attention to the effect of the digital transformation of society on teachers' professional identity. This interest is determined by the fact that Western societies encountered the processes of digital transformation in their everyday lives much earlier. This fact allowed foreign researchers to accumulate certain theoretical and methodological experience in the study of the professional identity of teachers of various social groups in the conditions of the digital transformation of society. The study of this experience allows posing the question of its implementation in Russian conditions with consideration of its sociocultural specifics.

Asking the question of what it means to be a teacher in the digital era, foreign researchers highlight the fact that the digital transformation of society and the wide spread of modern digital technology in the educational space of schools stimulate teachers to think and act differently. Scholars arrive to the conclusion that the digitalization of education contributes to the formation of a flexible and interactive "cybernetic" way of thinking saturated with network metaphors (Loveless, Williamson, 2013). Foreign scholars also focus on the questions of who should be teaching in a school, what is the image of a good teacher, and what is the best way to evaluate and reward schoolteachers. In their search for the answers to these questions, foreign researchers, particularly American ones, attribute special significance to the specifics of the American education system that determines the social contexts and professional opportunities within which the formation of teachers' professional identity takes place. Moreover, they adopt various identity construction theories trying to understand how teachers realize their professional "Self" in reformatory climate conditions (Buchanan, 2015; Yilmaz, Ilhan, 2017). Unlike Russian researchers, foreign scholars also pay great attention to the comparative study of professional self-awareness and professional identity of teachers from different age groups. Thereby, researchers indicate that young teachers primarily identify themselves with the images of professional "Self", while experienced teachers identify with the real professional community (Mahmoudi-Gahrouei et al., 2016). 
We should note here that foreign sociologists did not conduct special research of the professional identity of Russian young teachers in recent years. Meanwhile, international research collaborations examined a model of the professional identity of a teacher, its structural components, and mean values of professional identity in blocks of Latvian, Russian, and Belarusian samples. In accordance with the acquired results, researchers arrive at the conclusion that Russian teachers bear some similarities to their foreign colleagues (particularly Latvian teachers) found in the awareness of the high mission of their professional activity, focus on the development of students' competence, cultural, and value orientations, and focus on the improvement of the education level in society as a whole (Berberian et al., 2019). These results allow us to discuss the possibility of using foreign research practices in studying the professional identity of young Russian teachers.

In this context, both the main directions and methods of sociological study of teachers' professional identity draw scientific interest in terms of the possibility for the implementation of foreign research experience. Russian sociology mostly uses qualitative methods allowing identifying certain empirical trends when studying teachers' professional identity. In recent years, foreign sociology has been increasingly using qualitative methods that expand the possibilities of studying the internal motives of teachers' professional self-identification and the background (implicit) factors of the formation and transformation of their professional identity. Many Western sociological studies use the method of in-depth interview and narrative analysis of the acquired data (McLean, Price, 2019; Arvaja, 2016; Schultz, Ravitch, 2013). Moreover, it is not teachers in general who act as the interview subjects but individual social groups of teachers categorized either by pedagogical experience allowing to identify young and experienced teachers (Albuquerque et al., 2014) or by their status in professional community teacher, supervisor, headmaster (Brown, Heck, 2018).

Therefore, foreign scientific literature already reflects the results of the sociological study of various aspects of teachers' professional identity in the conditions of the digital transformation of society and school education. Foreign researchers have developed quite effective sociological instruments for the study of teachers' professional identity depending on their pedagogical experience and the level of professional mastery. This fact allows conducting comparative sociological studies aimed at identifying the specific characteristics of the professional identity of young and experienced teachers.

Positive theoretical and methodological experience in the study of teachers' professional identity accumulated in Russian and foreign sociology makes it possible to develop a methodological construct of the sociological study of young teachers' professional identity in the conditions of social, labor, and digital transformation of Russian society.

Being the product of the methodological consciousness of a scientist, a methodological construct presents a cognitive model of rational and project content setting the object field of a sociological study, its strategy, and ways and methods of fulfilling research objectives (Lubsky, 2017). A methodological construct of the sociological study includes, first, the theoretical knowledge forming its semantic apparatus in the form of a system of instrumental sociological concepts allowing determining research objectives and, second, the paradigms of its formulation and resolution. The difficulties researchers face in the development of a methodological construct of the sociological study of young teachers' professional identity are related to the fact that scientific discourse presents various perceptions of professional identity in general. Thus, some researchers view professional identity as the result of the process of self-identification, personalization, and self-organization that manifests in a person recognizing themselves as a representative of a specific profession and a member of a professional community (Shneider, 2007). Other researchers interpret professional identity as a person's adoption of professional value positions on social and psychological levels. According to this viewpoint, professional identity is characterized by a person's acceptance of the corresponding professional roles and 
functions, as well as them treating themselves as a professional (Povarenkov, 2002). Deriving from the fact that professional identity presents a product of continuous personal and professional development, the third group of researchers believes that this identity forms only at a relatively high level of professional mastery where the ideal, real, and professional self-images are consistently concurrent (Ermolaeva, 2017). Due to the fact that Russian sociology bears various definitions of professional identity determined by the differing methodological preferences of scholars, the multidimensionality of professional identity as a holistic social reality is constantly slipping away from research practices.

The methodological opportunities of the study of professional identity as a holistic social reality disclosed in the framework of soft conceptions of identity, based on the principles of constructive realism aimed at the discursive modeling of social reality. In the process of developing a methodological construct of the sociological study of young teachers' professional identity, it is necessary to consider that foreign research practices use both the "hard" and "soft" conceptions of identity. The "hard" conceptions formed within the essentialist approach to the interpretation of identity where an invariable set of identification characteristics is attributed to an individual or a social group. Such a "naturally determined" identity is something an individual or a social group have or should strive to possess. This identity is singular and stable, it requires fundamental similarity and a "strong feeling" as the basis for identification. "Soft" conceptions of identity formed within the constructivist approach to its interpretation. Due to constructivists, the idea of identity as something mobile and context-dependent rather than a stable core of "self-concept" preserved from beginning to end despite the external vicissitudes formed in research practices (Brubaker, Cooper, 2000).

Within the framework of the methodological construct of sociological study developed within the soft conception of identity, professional identity can be defined through the concept of unity - a young teacher's unity with themselves as a professional or their sameness to the referent professional group. The basic attributes of the professional identity of young teachers include their membership in the professional community, the presence of stable and relatively predictable professional relationships in it, the existing sense of professional security based on the expectations of mutual support, as well as the possibility of self-realization in the professional community and exerting influence on it. Young teachers' self-identification with the professional community largely depends on their ideas of the status and prestigiousness of the teaching profession in society, the degree of their satisfaction with the profession, the nature of labor motivation, and the understanding of professional values (Klimenko et al., 2018).

Within the soft conception of identity, young teachers' professional identity is examined as a discursive construct determined by professional context and various narratives of this identity. It should also be noted here that young teachers' professional identity forms when the following three factors are present. First, a young teacher has to consider themselves a part of the professional community not just "at their heart" but demonstrating it in professional behavior (the "I" factor). Second, the professional community must agree with this fact and demonstrate this consensus not in words but in deed (the "We" factor). Third, it is important that "others" should acknowledge this fact of belongingness (the "They" factor). The lack of one of the factors makes the professional identity of young teachers incomplete and problematic.

Three stages of the formation of the professional identity of young teachers can be identified within the methodological construct of its sociological study. The first stage involves the self-categorization of young teachers as the representatives of the professional community and the categorization of others (non-teachers) as the representatives of other professional communities. The adoption of certain professional values characteristic of a specific professional community by young teachers occurs at the second stage. The third stage composes the institutionalization of professional identity and its preservation as the model of professional behavior. The important functions of young teachers' professional identity are that it contributes 
to their integration into the professional community and determines the duration and effectiveness of young teachers' performance in their professional activities.

The methodological construct also comprises the real and ideal types of teachers' professional identity. First, it includes the positive type characterized by average or high evaluation of the status of the profession, priority position of professional identity among other identities, high degree of loyalty to corporate identity, positive attitude towards professional values, high satisfaction with the profession, high professional labor motivation, and orientation towards professional growth and career advancement. Second, there is the pseudo-positive type that involves average or high evaluation of the status of the profession, average or low position of professional identity among other identities, average loyalty/ritualism concerning corporate identity, low importance of professional values, imitation of satisfaction with the profession, a shift of emphasis in professional labor motivation towards rituals/conjuncture, average satisfaction with labor, and orientation towards career advancement. Third, there is the diffusive type that composes average/high evaluation of the status of the profession, low position of professional identity among other identities, low corporate identity loyalty, indifference to professional values, average/low satisfaction with the professional and average/low labor motivation, uncertainty in professional strategies, and the temporary nature of professional labor. Fourth, there is the crisis type characterized by low profession status, low position of professional identity among other identities, lack of loyalty to corporate identity, high or, on the contrary, low importance of professional values, low degree of satisfaction with the profession, equally low labor motivation, and orientation towards changing the profession (Klimenko et al., 2018).

P. Bourdieu's theory of social space and D. North's neo-institutional approach are suggested to be used in the study of external factors of the formation of young teachers' professional identity in new institutional conditions of general educational system functioning. We also consider the use of the mental programs theory (Lubsky, 2016) to be effective in the examination of the internal factors of the formation of young teachers' professional identity as it allows to identify the terminal and instrumental professional values of young teachers, as well as their values, and construct the models of their behavior in the professional sphere. The methodological potential in the study of the professional identity of young teachers in the conditions of social, labor, and digital transformation of Russian society is demonstrated primarily by G. Standing's precariat theory (Standing: 2011) adapted for Russian reality by Zh.T. Toshchenko (2018) and M. Castells' theory of information society.

\section{Conclusion}

In the study of young teachers' professional identity, Russian researchers face a range of theoretical and methodological difficulties related to the fact that research practices implement varying methodological approaches bearing different ideas of young teachers' professional identity and the factors of its formation. Meanwhile, the deployed methodological approaches allow resolving research objectives related to the study of young teachers' professional identity in traditional conditions of the school education system functioning that do not consider the effect of social, labor, and digital transformation on the formation of said identity.

The new methodological construct developed within the "soft conception" of identity with consideration of both Russian and foreign theoretical and methodological experience proposed in the article will allow acquiring new theoretical and empirical knowledge on the professional identity of young teachers as a holistic social reality in the conditions of social, labor, and digital transformation of Russian society.

\section{Acknowledgements}

The reported study was funded by RFBR, project number 19-311-90073. 


\section{References}

Albuquerque, A., Sa, P., Aranha, A., Resende, R. (2014). Teacher profile: The knowledge and the identity practices. Open Sports Sciences Journal, 7: 133-140.

Andrianov, A.V. (2014). Sotsialnaia adaptatsiia i professionalnaia identifikatsiia prepodavatelei fizicheskoi kultury [Social adaptation and professional identification of physical education teachers]: Ph.D. thesis. Belgorod State National Research University, Belgorod.

Arvaja, M. (2016). Building teacher identity through the process of positioning. Teaching and Teacher Education, 59: 392-402.

Berberian, A.S., Bogdanova, T.V., Silchenkova, S.V., Ermolaeva, E.B., Vardanian, N.T. (2019). Mezhdunarodnoe issledovanie professionalnoi identichnosti pedagoga [International study of the professional identity of a teacher]. Gumanitarii: aktualnye problemy gumanitarnoi nauki i obrazovaniia, 19(3): 306-319.

Brown, R., Heck, D. (2018). The construction of teacher identity in an alternative education context. Teaching and Teacher Education, 76: 50-57.

Brubaker, R., Cooper, F. (2000). Beyond "Identity". Theory and Society, 29(1): 1-47.

Buchanan, R. (2015). Teacher identity and agency in an era of accountability. Teachers and Teaching: Theory and Practice, 2(6): 700-719.

Chernikova, E.G., Ptashko, T.G., Rudenko, A.V. (2017). Adaptatsiia i professionalnoe razvitie molodykh pedagogov obshcheobrazovatelnykh organizatsii (po materialam obshcherossiiskogo sotsiologicheskogo issledovaniia) [Adaptation and professional development of young teachers of general educational organizations (based on the materials of an all-Russian sociological study)]. South Ural State Humanitarian Pedagogical University bulletin, 7: 114-122.

Ermolaeva, E.P. (2017). "Sovremennye tendentsii dinamiki professionalnoi identichnosti [Modern trends in the dynamics of professional identity]", in: A. L. Zhuravlev, V. A. Koltsova (eds), Fundamentalnye i prikladnye issledovaniia sovremennoi psikhologii: rezultaty i perspektivy razvitiia. Moscow: "Psychological Institute of Russian Academy of Education" publishing house.

Gladkaia, I.V. (2012). Molodye uchitelia o svoei gotovnosti k professionalnoi deiatelnosti [Young teachers on their readiness for professional activity]. Izvestia: Herzen University Journal of Humanities and Sciences. Series: Pedagogika, 148: 104-118.

Howe, N., Strauss, W. (1991). Generations: The History of America's Future, 1584 to 2069. New York: William Morrow \& Company.

Khoshimova, N.M., Tagoeva, S.M. (2017). Trudnosti i nedostatki v professionalnoi deiatelnosti nachinaiushchikh uchitelei [Difficulties and weaknesses of novice teachers' professional activity]. Scientific notes of the Khujand State University named after academician B. Gafurov. Humanitarian sciences, 1: 234-237.

Klimenko, L.V., Mosiyenko, O.S., Nor-Arevyan, O.A., Posukhova, O.Yu. (2018). Professionalnaia identichnost predstavitelei sotsialno orientirovannykh professii $\mathrm{v}$ usloviiakh prekariatizatsii rossiiskogo obshchestva [Professional identity of the representatives of socially oriented professions in the conditions of precariatization of Russian society]. Rostov-on-Don: Fond nauki i obrazovaniia.

Klimenko, L.V., Posukhova, O.IU. (2017). Professionalnaia identichnost gorodskikh uchitelei v usloviiakh modernizatsii instituta obrazovaniia [Professional identity of urban teachers in the conditions of modernization of education]. Journal of Institutional Studies, 9(2): 137-153.

Klimenko, L.V., Posukhova, O.Y. (2018). Professional identity of schoolteachers in the context of socio-historical dynamics of Russian society. International Journal of Educational Management, 32(5): 813-824.

Loveless, A., Williamson, B. (2013). Learning identities in a digital age: Rethinking creativity, education and technology. London: Routledge. 
Lubsky, A.V., ed. (2016). Mentalnye programmy i modeli sotsialnogo povedeniia v rossiiskom obshchestve: monografiia [Mental programs and models of social behavior in Russian society]. Postov-on-Don: Fond nauki i obrazovaniia.

Lubsky, A.V. (2017). Metodologiia sotsialnogo issledovaniia [Social research methodology]. Moscow: INFRA-M.

Luchkina, T.V. (2012). Puti stanovleniia professionalizma molodogo uchitelia v sovremennoi shkole [The ways of development of professionalizm in young teachers in a modern school]. Scholarly Notes of Transbaikal State University. Series: Pedagogika i psikhologiia, 5: 7-16.

Mahmoudi-Gahrouei, V., Tavakoli, M., Hamman, D. (2016). Understanding what is possible across a career: professional identity development beyond transition to teaching. Asia Pacific Education Review, 17(4): 581-597.

Maslinskii, K.A., Ivaniushina, V.A. (2016). Ostatsia uchitelem? Faktory, vliiaiushchie na otnoshenie k ukhodu iz uchitelskoi professii [Remain a Teacher? Factors Influencing Attitudes to Leaving the Teaching Profession] (trans. from English by E. Shadrina). Voprosy obrazovaniia, 4: 8-30.

Mclean, N., PRICE, L. (2019). Identity formation among novice academic teachers - a longitudinal study. Studies in higher education, 44(6): 990-1003.

Povarenkov, Iu.P. (2002). Psikhologicheskoe soderzhanie professionalnogo stanovleniia cheloveka. [Psychological content of a person's professional development]. Moscow: Publishing house of the University of the Russian Academy of Education.

Schultz, K., Ravitch, S.M. (2013). Narratives of learning to teach: Taking on professional identities. Journal of Teacher Education, 64(1), 35-46.

Shakurova, A.V. (2014). Professionalnaia identichnost uchitelei kak subektov trudovoi deiatelnosti [Professional identity of teachers as the subjects of labor activity]. Nizhni Novgorod: "Nauchno-Issledovatelskii Sotsiologicheskii Tsentr" publishing house.

Shchetkina, I.A., Zakharova, E.Iu., Okuneva, N.I. (2015). Otnoshenie molodykh pedagogov $\mathrm{k}$ professii uchitelia: sotsiologicheskii analiz [Young pedagogs' attitude to the teaching profession: sociological analysis]. Uchenye zapiski Zabaikalskogo gosudarstvennogo universiteta. Filosofiia, sotsiologiia, kulturologiia, sotsialnaia rabota, 4: 191-197.

Shevchenko, O.A. (2014). Empiricheskoe issledovanie professionalnogo razvitiia molodykh uchitelei v sisteme postdiplomnogo pedagogicheskogo obrazovaniia [An empirical study of young techers' professional development in the system of postgraduate pedagogical education]. Kontsept, 7: 16-20.

Shliakov, D.V. (2008). Sotsialno-professionalnaia identifikatsiia uchitelia: sotsiologicheskii analiz [Social and professional identification of a teacher: sociological analysis]: $\mathrm{Ph} . \mathrm{D}$. thesis. South Federal University, Rostov-on-Don.

Shneider, L.B. (2007). Lichnostnaia, gendernaia i professionalnaia identichnost: teoriia i metody diagnostiki [Personal, gender, and professional identity: theory and diagnostic methods]. Moscow: Moscow Psychological and Social Institute.

Siniakova, M.G., Shneider, L.B. (2011). Empiricheskoe izuchenie kharakteristik i tipov professionalnoi identichnosti gorodskikh pedagogov [An empirical study of the characteristics and types of urban teachers' professional identity]. Aktualnye problemy psikhologicheskogo znaniia, 1: 48-61.

Sivrikova, N.V., Chernikova, E.G., Sokolova, N.A. (2017). Udovletvorennost zhizniu i obrazovatelnym protsessom kak prediktory sotsialno-psikhologicheskoi adaptatsii uchitelei [Satisfaction with life and educational process as predictors of teachers' socio-psychological adaptation]. Novosibirsk State Pedagogical University bulletin, 7(6): $87-100$.

Standing, G. (2011). The Precariat: The New Dangerous Class. London: Bloomsbury Academic.

Toshchenko, Zh.T. (2018). Prekariat: ot protoklassa k novomu klassu. [Precariat: from a protoclass to a new class]. Moscow: Nauka. 
Volchik, V.V., Posukhova, O. Iu. (2017). Reformy v sfere obrazovaniia i prekariatizatsiia uchitelei [Education reforms and precariatization of teachers]. Terra Economicus, 15(2): 122-138.

Yilmaz, F., Ilhan, M. (2017). Who are teachers? A study of identity hierarchy. Cogent Education, 4(1), 1384638. 